\title{
Red Sea gravity currents cascade near-reef phytoplankton to the twilight zone
}

\author{
Helge Niemann ${ }^{1,4, *}$, Claudio Richter ${ }^{1}$, Henk M. Jonkers ${ }^{2}$, Mohammad I. Badran ${ }^{3}$ \\ ${ }^{1}$ Center for Tropical Marine Ecology, Fahrenheitstr. 6, 28359 Bremen, Germany \\ ${ }^{2}$ Max Planck Institute for Marine Microbiology, Celsiusstr. 1, 28359 Bremen, Germany \\ ${ }^{3}$ Marine Science Station, The University of Jordan and Yarmouk University, PO Box 195, Aqaba, Jordan \\ ${ }^{4}$ Present address: Max Planck Institute for Marine Microbiology, Celsiusstr. 1, 28359 Bremen, Germany
}

\begin{abstract}
Cross-reef variations of sea water density, currents and phytoplankton pigments were investigated in the northern Gulf of Aqaba, Red Sea. Differential cooling of near- and offshore surface water during cold winter nights results in cross-shore gradients of density $(\sigma-t)$ triggering gravity currents which cascade downslope along sandy valleys. Two 4-wk deployments of 3-D acoustic current meters showed that cross-shore currents near the sea bed (35 and $90 \mathrm{~m}$ ) were 2- to 5-fold higher than long-shore currents, inversely related to surface flow and highly correlated with seasonally detrended diel variations in seawater temperature. Cross-shore flow varied during the course of the night, with offshore pulses of up to $15 \mathrm{~cm} \mathrm{~s}^{-1}$ associated with sudden temperature drops of $\sim 0.15^{\circ} \mathrm{C}$. Spatial distribution of chl a pigments shows that phytoplankton enriched nearshore waters are entrained in the gravity currents to depths $>300 \mathrm{~m}$. Gravity currents may therefore provide an important and previously overlooked pathway of reef-borne material to the food-impoverished deeper strata of the Red Sea.
\end{abstract}

KEY WORDS: Gulf of Aqaba - Red Sea · Gravity currents - Density cascading · Advection · Phytoplankton $\cdot \mathrm{Chl} \mathrm{a} \cdot$ Coral reef ecology

Resale or republication not permitted without written consent of the publisher

\section{INTRODUCTION}

Interactions between currents and waves with shelf topography are known to determine the distribution and fate of floating particles and suspended matter in near-shore waters (Wilson \& Roberts 1995, Leichter et al. 1998,) and, hence, to govern food supply and recruitment patterns of the benthos (Pineda 1994, 1999). Little is known, however, about the fine-scale current field mediating the exchange of material between the coral reef and the adjacent oligotrophic ocean and deep benthos, respectively. The few studies published to date focus on the supply of nutrients and plankton to the reef due to internal tides, tidal bores and topographic upwelling (Roberts et al. 1992, Leichter et al. 1998, 2003) which may cause up to a 40-fold increase in nutrient concentrations. Long period waves (infragravity) (Roberts et al. 1992), gravity currents in response to turbidity and evapora- tive cooling (Wolanski et al. 1994), extreme meteorological events, e.g. cold fronts (Wilson \& Roberts 1995) or typhoons (Nadaoka et al. 2001), in contrast, cause export of reef sediments and other suspended material. Interdisciplinary investigations linking near-shore hydrography to the potential export of near-reef organic matter to the oligotrophic surrounding ecosystems are rare (Delesalle et al. 1998, Hata et al. 1998) or entirely non-existent for the the Red Sea. The present study aims to close this knowledge gap by investigating the flow of near-reef phytoplankton between a Gulf of Aqaba (Red Sea) coral reef, the adjacent open ocean and deep benthos.

\section{MATERIALS AND METHODS}

Area description. The Gulf of Aqaba is the northeastern extension of the Red Sea. Due to its tectonic 
settings the Gulf has a unique depth-length relationship (Marcos 1970, Klinker et al. 1978) resulting in a very narrow fringe of shallow waters that host a patchy reef community. Northerly winds with a mean speed of $4.4 \mathrm{~m} \mathrm{~s}^{-1}$ (Hulings 1979) dominate the water body, which is nearly completely enclosed by desert. The climate is arid: precipitation is in the magnitude of 25 to $35 \mathrm{~mm} \mathrm{yr}^{-1}$ and evaporation is in the magnitude of 2 to $4.2 \mathrm{~m} \mathrm{yr}^{-1}$ (Assaf \& Kessler 1976, Levanon-Spanier et al. 1979, Genin et al. 1995). Humidity ranges from 15 to $45 \%$ during summer and 30 to $90 \%$ during winter. Water temperature is relatively constant at ca. $21^{\circ} \mathrm{C}$ throughout the entire water column during winter, but a relatively weak stratification is established, when the upper water masses may reach $26^{\circ} \mathrm{C}$ during the summer months (Paldor \& Anati 1979, Genin et al. 1995, Badran 2001, Rasheed et al. 2002). The Gulf is a microtidal environment characterised by spring and neap tides of 1.0 and $0.5 \mathrm{~m}$, respectively. Currents in the northern Gulf are generally weak with velocities $<25 \mathrm{~cm} \mathrm{~s}^{-1}$ (Genin \& Paldor 1998). Mesoscale currents were attributed to wind (Berman et al. 2000) or to large-scale thermohaline convection (Klinker et al. 1976, Paldor \& Anati 1979). Further information on various aspects of the Gulf of Aqaba can be found in Reiss \& Hottinger (1984), Hempel \& Richter (2002) and references therein.

Site selection. Bathymetric measurements in the coral reserve next to the Marine Science Station, Aqaba, were carried out prior to hydrographical and biological measurements yielding a bathymetric isoline chart (Fig. 1). The chart consists of ca. 1000 data triplets of longitude, latitude and depth measured by

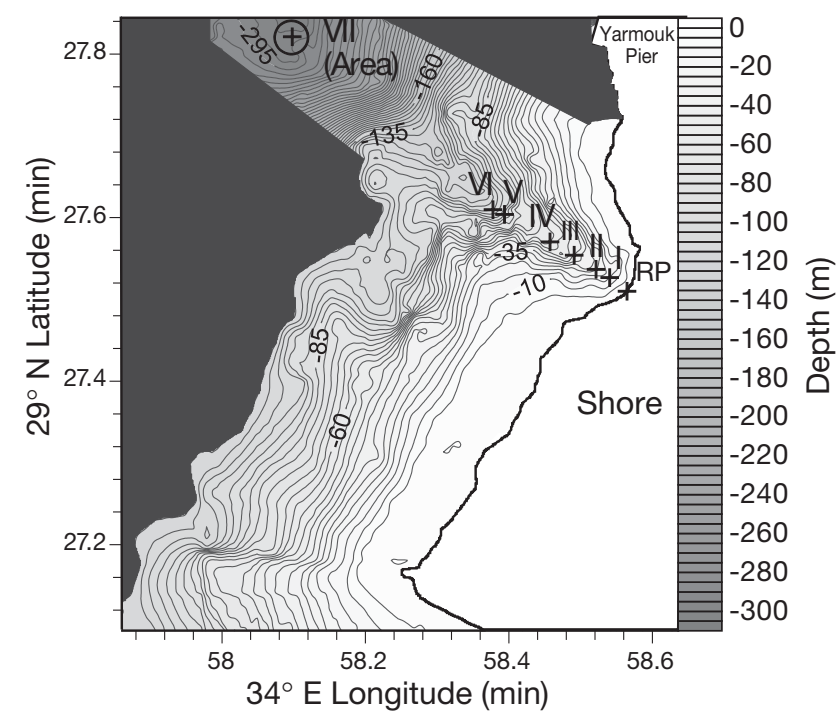

Fig. 1. Bathymetric chart of the coral reserve with positions of measurement stations (I-VII) along a dominant submarine valley. $\mathrm{RP}=$ shoreline reference point. Dark grey: areas not mapped means of a global positioning system receiver (GPS), sonar and a pressure sensor. One prominent feature is a sandy valley intruding the steep slope in the northern part of the reserve. A transect was established along the main axis of this valley in order to measure currents, phytoplankton pigments, salinity and temperature, because bathymetric funnelling of hyperpycnal water was expected to result in higher velocities of gravity currents flowing over the sea floor. Several moorings (Stns I-VI) with different maximum depth were deployed to facilitate measurements and sampling at fixed positions. For the offshore station (Stn VII) a mooring could not be deployed due to heavy ship traffic, and was therefore approached with the aid of a GPS. Positions of stations are shown in Fig. 1 while a schematic overview of the transect is shown in Fig. 2.

Data collection and instruments specifications. Current velocity and temperature time series data were recorded by means of 23 -D acoustic FSI (Falmouth Scientific) current meters (accuracy: $\pm 2 \%$, response time: 60 to $70 \mathrm{~ms}$ ). Both FSIs were fixed at Stn III in January and Stn V in February 2001 near the surface $(-5 \mathrm{~m})$ and close to the sea bed (1 $\mathrm{m}$ above sea floor), respectively. The sampling interval was set to 2 min over mooring periods of $4 \mathrm{wk}$ before retrieval, data saving and re-installation. Temperature loggers of the current meters were inter-calibrated with a CTD (Ocean Sensors Model 453). The cross-shore direction $\left(129^{\circ}\right)$ was estimated from the direction of the major submarine valley in the northern part of the reef. Thus, a negative cross-shore velocity is directed offshore; a positive long-shore velocity is directed northeast towards the head of the Gulf. Hour-specific averages

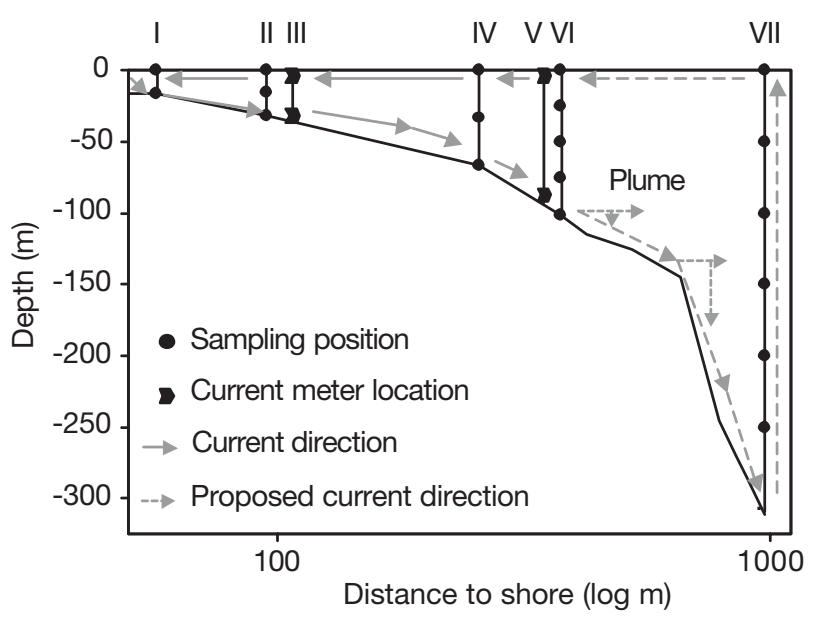

Fig. 2. Measurement transect with sampling stations. Circles mark the depth of water samples drawn for chl a measurements, while black arrows mark temporary current meter positions (Dec-Jan, Stn III; Feb, Stn V). Grey arrows indicate measured (solid line, at Stns II and V) and proposed (dashed line, between Stns VI and VII) current directions 
from raw data collected for 1 specific hour $(\mathrm{n}>540)$ over the entire sampling period were calculated prior to plotting Fig. 3. In contrast, raw data of seawater temperature and current velocities were averaged hourly $(n=30)$ prior to statistical analysis and plotting of Fig. 4 , in order to even out possible spikes in the raw data. Vertical profiles (surface to $2 \mathrm{~m}$ above sea floor) of salinity and temperature were measured at Stns I, II, IV, VI and VII with the CTD device from mid December 2000 to the end of January 2001. CTD measurement intervals were set to $1 \mathrm{~s}$, and descending and ascending speed was $1 \mathrm{~m} \mathrm{~s}^{-1}$. Additionally, water samples were taken from different depths (Fig. 2) by means of 51 Niskin bottles. Directly after sampling, seawater was processed in the laboratory for further analysis on chl a concentrations: $4 \mathrm{l}$ of each sample was filtered through Whatmann GF/F ( $4.7 \mathrm{~cm}$ in diameter) filters with a vacuum of 0.5 bars. Filters were stored in Eppendorf caps, wrapped in aluminium foil and kept at $-80^{\circ} \mathrm{C}$ until HPLC and spectroscopic analysis. Chl a was identified and quantified according to the method of Wright et al. (1991). HPLC and spectroscopic analysis was carried out with a Waters 2690 Separation

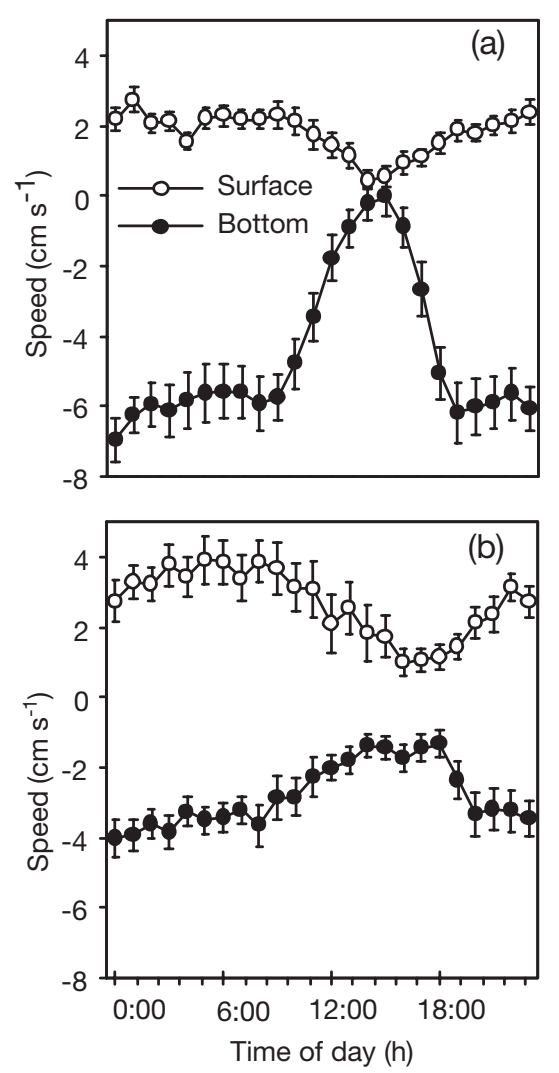

Fig. 3. Daily time course of averaged cross-shore current velocities at the surface and the bottom at (a) Stn III (35 m) and (b) Stn V (90 m). Hourly averages were calculated from hourspecific data $\left(\mathrm{n}=30\right.$ measurements $\mathrm{h}^{-1} \times$ days of deployment $=$ 590 and 540 for Stns III and V, respectively); error bars = SE
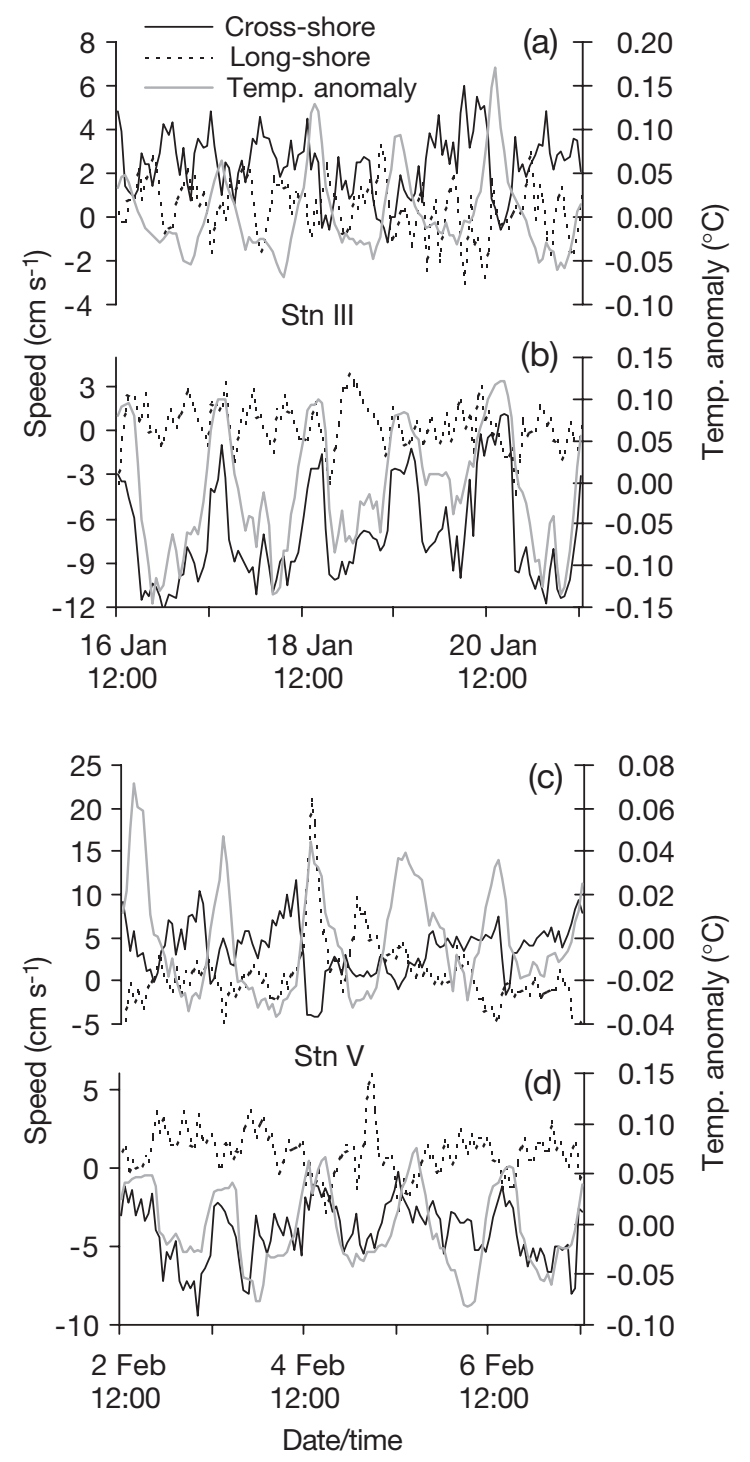

Fig. 4. Partial raw data set of hourly averages $(1 \mathrm{~h}$ : $\mathrm{n}=30)$ showing a representative time series of cross-shore current velocity, long-shore current velocity and temperature anomaly at $(a, c)$ the surface and $(b, d)$ the bottom at Stns III and V, respectively. Nocturnal temperature decreases are associated with increased offshore flow at the bottom. This pattern is anti-cyclic at the surface. Note that instrument deployments were not simultaneous at Stns III and V

Module equipped with a Waters PDA 996 photo diode array detector, allowing the measurement of full absorption spectra used together with known retention times and co-elution (with known standard solutions) to identify chromatogram peaks.

Sampling design. Weekly samplings $(n=5)$ were carried out during day and night starting at 12:00 and 03:00 h, respectively. On each occasion the cross-shore section was sampled 3 times successively: twice by CTD casts and once by a combined CTD cast with water sampling for pigment analysis. 


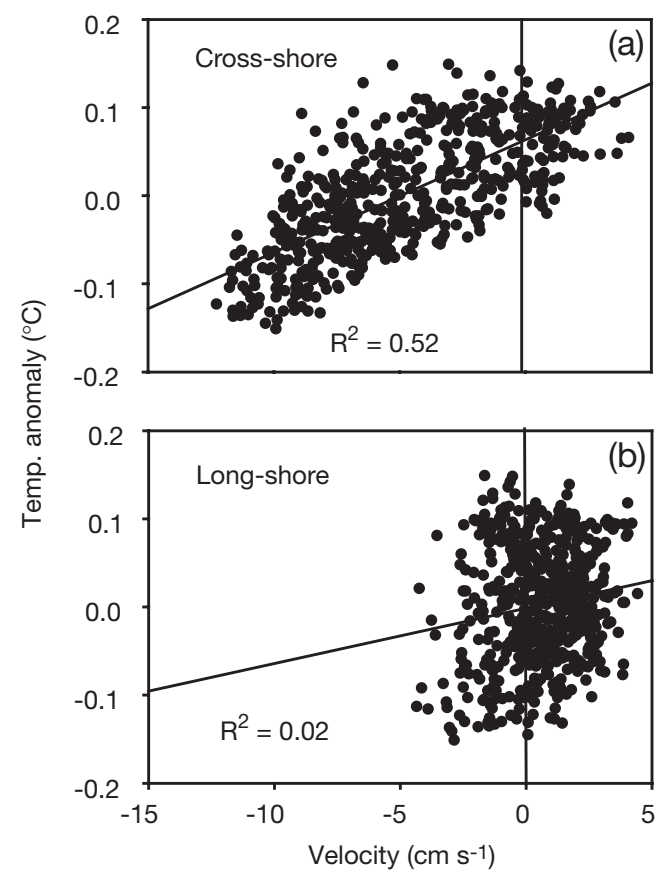

Fig. 5. Correlation between temperature anomaly and (a) crossshore current velocity and (b) long-shore current velocity of bottom waters at Stn III $(\mathrm{n}=590)$

\section{RESULTS}

\section{Current regime and temperature series}

The seasonal cooling of the water column was superimposed onto the diel oscillations of seawater temperature. In order to separate diel from seasonal variations, the diel temperature anomaly was calculated, i.e. the deviation of temperature in ${ }^{\circ} \mathrm{C}$ from the seasonal cooling trend.

Current velocities showed a distinct diel pattern (Fig. 3). Near the sea bed, cross-shore currents were highest during the night and minimal during the day, with lower values and a phase shift of ca. $2 \mathrm{~h}$ at Stn V. Surface currents showed a corresponding pattern with night-time maxima and daytime minima in the crossshore component. The long-shore component, in contrast, showed no describable temporal pattern.

Near the sea bed, cross-shore current velocity was linked to temperature anomaly (Fig. 4). That is, a temperature decrease was associated with increased offshore flow on the sea floor and onshore flow at the surface. Moreover, temperature anomaly alone explained more than half of the variations in cross-shore current velocity near the sea bed close to the shore (Stn III, $\mathrm{R}^{2}=0.52$, Fig. 5a) while the fit was poorer further offshore $\left(\operatorname{Stn} V, \mathrm{R}^{2}=0.24\right)$. Furthermore, both time series revealed several peaks of cross-shore current velocity and temperature anomaly at night-time, indicating that these phenomena are abrupt (Fig. 4). Long-shore current velocities, in contrast, were lower in magnitude and independent of temperature (Stn III, $\mathrm{R}^{2}=$ 0.02, Fig. 5b; Stn V, $R^{2}=0.01$ ). Near the surface, temperature anomaly and cross-shore velocity had an anti-cyclical pattern: a decrease in temperature was linked to an enhanced onshore flow (Fig. 4). However, a poor correlation between temperature anomaly and surface cross-shore current velocity $\left(\mathrm{R}^{2} \leq 0.05\right)$ indicates a strong impact of factors other than temperature anomaly.

Bottom current velocities exceeded surface currents at all times ( $\mathrm{p}=0.01, t$-test) with an average velocity of $4.6 \mathrm{~cm} \mathrm{~s}^{-1}$ compared to $2.1 \mathrm{~cm} \mathrm{~s}^{-1}$ at Stn III and $3 \mathrm{~cm} \mathrm{~s}^{-1}$ compared to $2.7 \mathrm{~cm} \mathrm{~s}^{-1}$ at Stn V, respectively. Moreover, currents were generally pointing in opposite

\section{(a)}

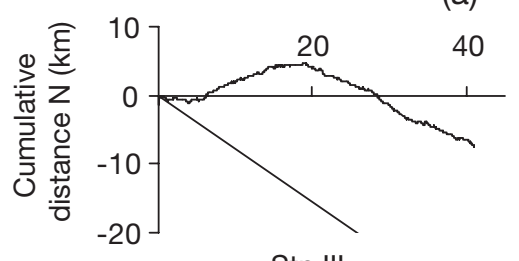

Stn III

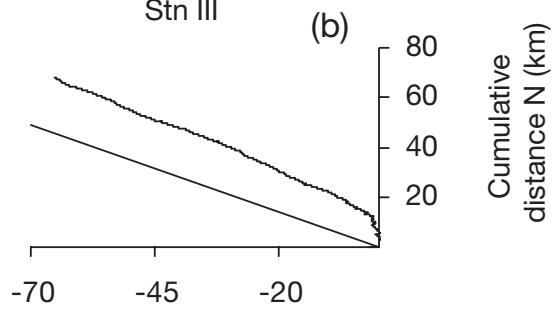

(c)
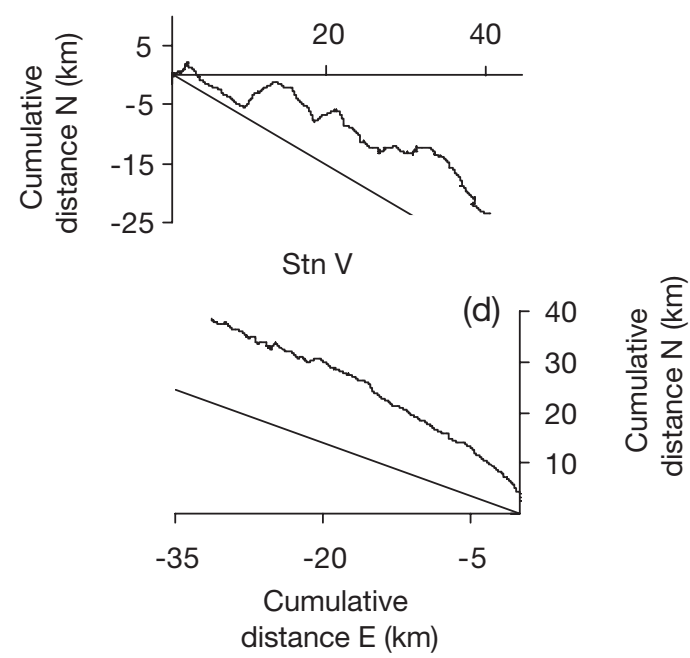

Fig. 6. Cumulative distances of $(\mathrm{a}, \mathrm{c})$ surface and $(\mathrm{b}, \mathrm{d})$ bottom currents at Stns III and V, respectively ( $\mathrm{n}=$ ca. 20000 ). Straight lines mark the direction of the sandy valley. Bottom and surface currents point in opposite directions: surface flow is onshore (SE) with moderate changes in direction while bottom flow is offshore (NW) 
directions: bottom current directions were sharply offshore and surface currents onshore with moderate changes in direction (Fig. 6).

\section{Density and chl a distribution}

Contour plots were computed with the aid of the Surfer 7.0 software package. The gridding method used was triangulation with linear interpolation, and plotting was without contour smoothing.

Nocturnal offshore bottom currents temporally coincided with distinct layers of dense water near the sea bed. Fig. 7a shows increased seawater density of bottom waters, with nose shapes typical for density currents (Sturman et al. 1999, Jungclaus \& Mellor 2000). The nose shape results from the velocity maximum being in the middle of the current's head, while frictional forces at the upper and lower boundary have decelerating effects (Kneller \& Buckee 2000). Fig. 7b
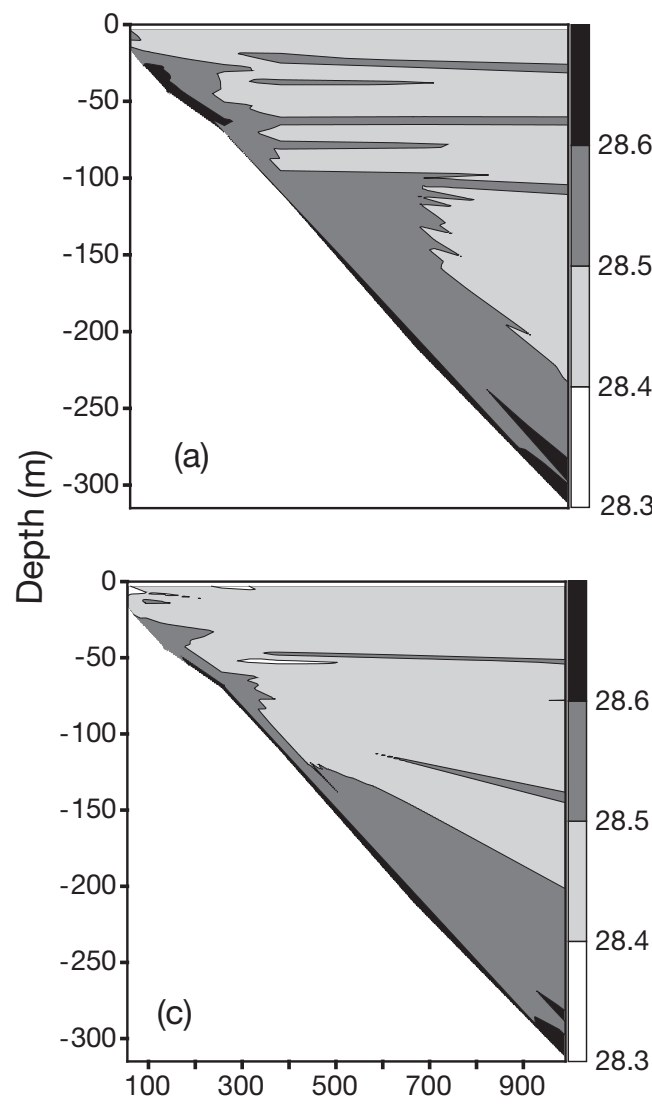

shows that the nocturnal, dense bottom layer was a commonly encountered feature, while density values for the same area had a higher variability during the day (Fig. 8b). Compared to daytime (Fig. 7c), the overall night-time density was higher; particularly the water masses from the near-shore region (surface and down to $50 \mathrm{~m}$ depth) were lighter during daytime. Offshore waters and deep waters (Stn VII), in contrast, did not show high density changes between day- and night-time. Correlation of $\sigma$-t versus temperature and salinity revealed that density changes were mainly determined by seawater temperature fluctuations (Fig. 8a) whereas salinity had only a moderate effect on $\sigma$-t (Fig. 8b).

Nocturnal values of chl a mass per unit area (Fig. 9) were significantly lower at Stns I-VI ( $n=5, \mathrm{p} \leq 0.05$, $t$-test) and significantly higher at Stn VII ( $\mathrm{n}=5, \mathrm{p} \leq$ $0.05, t$-test) compared to daytime values, while the integrated amount of $\mathrm{chl}$ a over the entire transect was almost equal for day- and night-time. Moreover, the

Distance to shore $(\mathrm{m})$

Fig. 7. Vertical distribution of mean seawater density (a) at night and (c) during daytime with associated SE (b) at night and (d) during daytime. Mean values are of 5 sampling dates $(n=5)$ on which $2 \times 3$ subsequent cast series were drawn (day and night). Near-shore bottom water masses ( $<150 \mathrm{~m}$ depth) at night are characterised by high $\sigma$-t values that are in the same range as deep bottom (300 $\mathrm{m}$ depth) water masses. In contrast, near-shore bottom waters $(<150 \mathrm{~m}$ depth) were less dense during daytime. $\mathrm{SE}$ in surface waters $(<150 \mathrm{~m}$ depth) indicate a higher variability of $\sigma$-t values compared to deep waters $(>150 \mathrm{~m}$ depth). Plume extensions from near-shore to offshore are therefore likely to be a transient feature. Nocturnal density maxima in shallow bottom waters are, in contrast, regularly occurring 


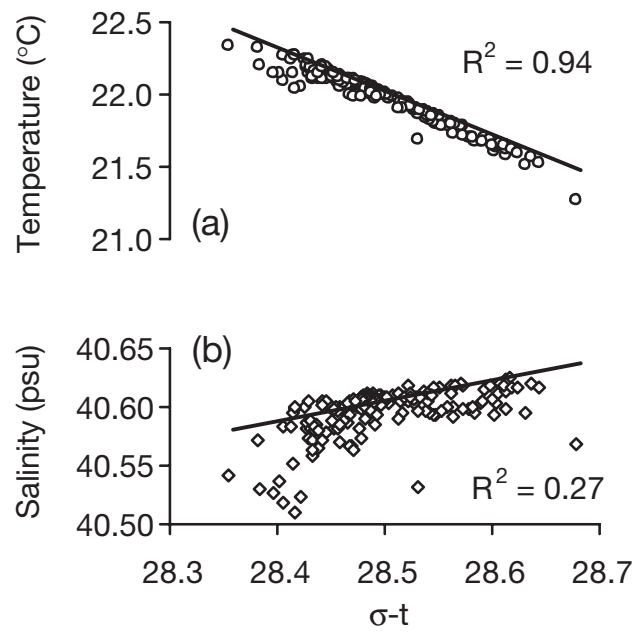

Fig. 8. Correlation between $\sigma$-t and (a) seawater temperature and (b) salinity. The high correlation between temperature and $\sigma$-t indicates that changes in $\sigma$-t were dependent on temperature changes. Salinity changes, in contrast, had only a moderate effect on $\sigma$ - $t$

sum of differences from Stns I-VI was almost equal to the difference at Stn VII. The spatial distribution of chl a concentrations (Fig. 10) reveal that a nocturnal decrease of chl $a$ in the near-shore region coincided temporally with an increase in surface, intermediate and surprisingly deep waters (except bottom waters) at the offshore Stn VII. The daytime situation (Fig. 10c), in contrast, is characterised by comparably high values in the near-shore region and in bottom waters at Stn VII, while the overlying water column, especially at $-250 \mathrm{~m}$, contains comparably low amounts of chl a. Daytime chl a concentrations show a higher variability, particularly in intermediate, near-shore waters (Fig. 10b,d) while offshore bottom waters were almost equally variable.

\section{DISCUSSION}

This study shows that thermohaline currents - typically associated with the large- and mesoscale circulation in polar and temperate seas - are a daily finescale phenomenon in the subtropical, semi-enclosed Gulf of Aqaba in winter, driving the cross-shelf circulation in this steeply sloped, microtidal and low advective environment.

The close inverse relationship between gravity flows and temperature corroborates with earlier model results showing that mixing in the Gulf of Aqaba is mainly determined by sensible and latent heat loss (Genin et al. 1995, Badran 2001), while other factors (e.g. radiation, wind speed, humidity) appear to be less important. But in contrast to earlier reports the present study suggests that much of the convective overturn occurs at the margins, rather than at the centre of the Gulf. Air temperatures in the desert-enclosed Red Sea may drop below $10^{\circ} \mathrm{C}$ on cold winter nights resulting in extreme heat loss from the warm sea surface (Reiss \& Hottinger 1984). In the shallow waters of the reef flats and lagoons, the upward heat flux from warm deeper waters is limited. As a result, the higher heat loss per unit volume leads to intense cooling, the formation of hyperpycnal waters and subsequent downwelling along the coast (Huthance 1981, Wilson \& Roberts 1995). Ensuing gravity flows are governed by a balance of buoyant, inert and viscous forces, discussed in detail by Wilson \& Roberts (1995), Sturman et al. (1999), Kneller \& Buckee (2000) and references therein. In weakly stratified waters, such as the hibernal Gulf of Aqaba (Plähn et al. 2002), even small density differences are sufficient to trigger density currents, which may travel considerable distances. The pulse-like flows registered during this study (Fig. 4) suggest a seesaw of viscous versus buoyancy forces, resulting in an intermittent release of gravity currents; where the relief is flat and viscous forces exceed the pull of gravity, hyperpycnal water accumulates, such as over the shallow expanses of the reef flat. As the hyperpycnal waters continue to both cool and extend across the steeper fore-reef, spillover and entrainment triggers a cascade of hyperpycnal waters flushing near-shore surface waters downslope. Taking into account the multitude of factors potentially influencing currents in the ocean, the correlation between temperature anomaly and cross-shore current velocity (Fig. 5) provides significant evidence for an offshorewards cross-shore current at Stn III that is mainly driven by temperature.

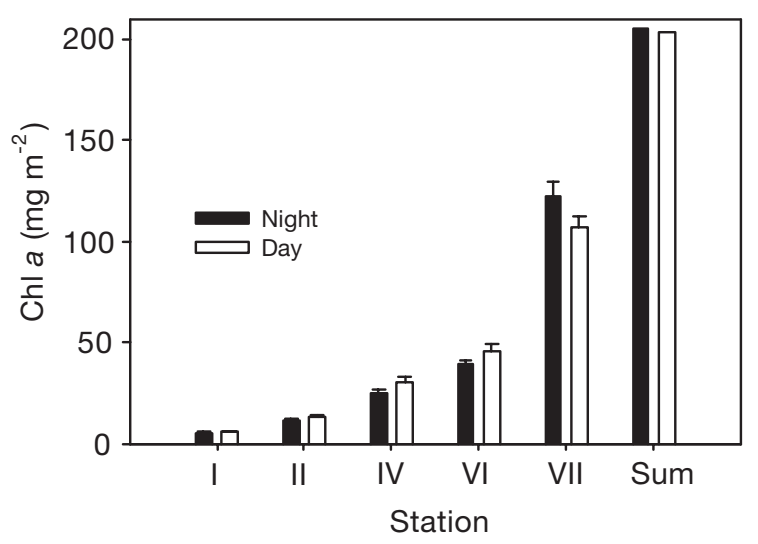

Fig. 9. Chl a mass per unit area. Nocturnal masses per unit area of chl a were lower in the near-shore area (Stns I to V) but higher at the offshore Stn VII compared to daytime values. The integrated chl a mass per unit area over the entire transect (Stns I to VII) is almost equal for day and night 

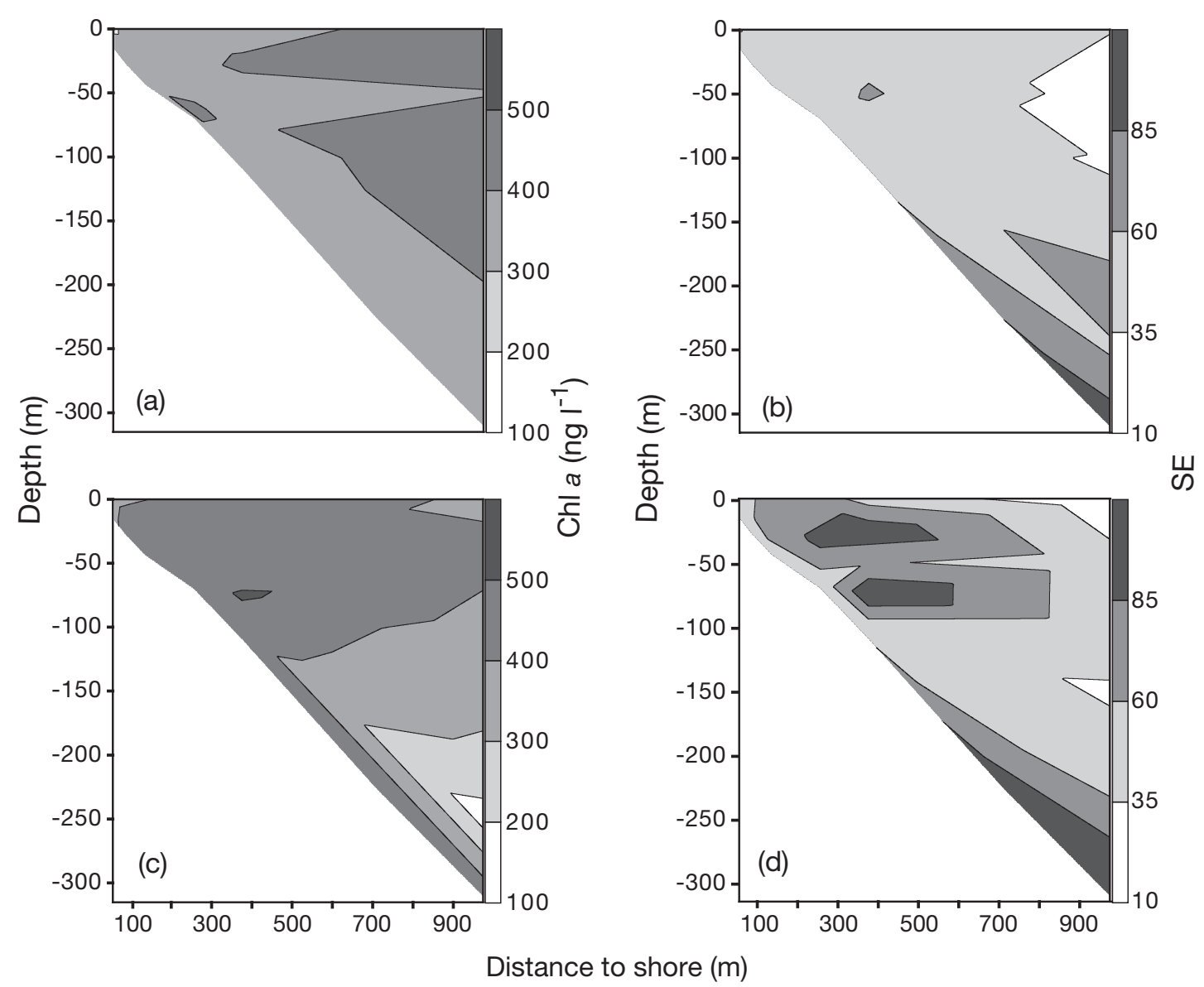

Fig. 10. Vertical distribution of mean $(n=5)$ chl a concentrations (a) at night- and (c) during daytime with associated SE $(b)$ at night and (d) during daytime

Generally, gravity currents feature 2 successive stages (Didden \& Maxworthy 1982): an inert/buoyant regime, where buoyant forces are balanced by inert forces resulting in a constant velocity, and a viscous/buoyant flow regime characterised by a decelerating advance velocity further downstream, in response to turbulent mixing with ambient waters (Kneller \& Buckee 2000). Good indication of the latter is given by a lower correlation of temperature anomaly and cross-shore current velocity at the offshore station (Stn V, $90 \mathrm{~m}$ ) where peaks of current velocity are lower and delayed compared to the upstream position (Stn III, $30 \mathrm{~m}$ ). The phase shift between current maxima (Stn III vs Stn V, 2 h) corresponds well with the average bottom flow ( 3 to $5 \mathrm{~cm} \mathrm{~s}^{-1}$ ) and distance $(\sim 300 \mathrm{~m})$ between stations.

We calculated the vertical distribution of cross-shore current velocities at Stn III using a simple, linear integration approach resulting in the vector diagram of Fig. 11. This approach is based on 2 end members, i.e. the actual recordings of the 2 current meters $(1 \mathrm{~m}$ above sea floor and $5 \mathrm{~m}$ depth). For the integration we used the mean cross-shore current velocity from 18:00 to $06: 00 \mathrm{~h}$

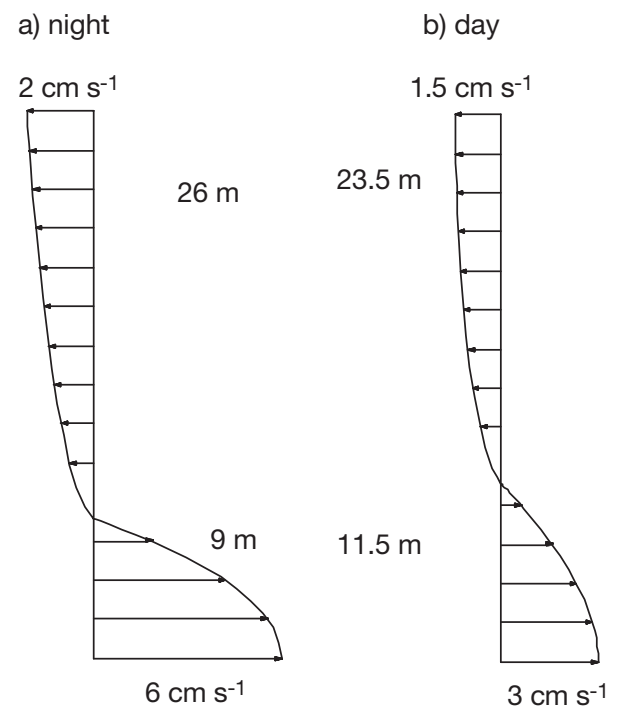

Fig. 11. Vertical cross-shore current velocity profile (a) at night and (b) during daytime, based on mean current velocities ( $\mathrm{n}=$ ca. 10000 for day and night, respectively), showing that the gravity flow occupies the lower third or less of the water column 
and from 06:00 to 18:00 $\mathrm{h}$ for night-time and daytime, respectively. This approach is simplified in that it neglects turbulent currents that most likely occur between the onshore and offshore flowing water masses. This problem can be solved in future studies by using an ADCP (acoustic doppler current profiler) device. However, the integration approach shows that density currents in the Gulf originating from shallow areas result in a jet of cold water that is concentrated in a narrow layer occupying about a third of the water column.

In spite of hard evidence, our data on deceleration of flow speeds, cross-shelf distributions of density and chl $a$ (see next paragraph), suggest that gravity currents extend well beyond the euphotic zone, thus providing a previously overlooked pathway of surface primary production to the twilight zone (200 to $300 \mathrm{~m}$ depth).

Downslope transport of phytoplankton is indicated by the cross-shelf distribution of chl a (Fig. 10) at nighttime, which shows only negligible along-slope variations in chl a near the bottom (Fig. 10a,c) throughout the study period (cf. the standard error (SE) values in this region, Fig. 10 b,d), in marked contrast to the strong vertical chl a gradients, particularly at the offshore station during the day (Fig. 10c). In situ production at $300 \mathrm{~m}$ depth can be ruled out as well as changes due to active migration (which are spatially much smaller for e.g. dinoflagellates), suggesting a physical mechanism of translocation from surface to bottom waters which, in association with temporally cooccurring enhanced current velocity, negative temperature anomaly and increased $\sigma$-t values, indicates density currents as the most likely transport mechanism. The lack of significant day-night differences in the overall integrated chl a values (Fig. 9) shows that the observed cross-shelf chl a distribution patterns are mainly due to the translocation of biomass within the coastal circulation, advecting near-reef phytoplankton to deep offshore waters, analogous to density cascading of sediments recorded from the Bahamas by Wilson \& Roberts $(1992,1995)$. A fraction of the main current plumes out laterally while the other part continues to flow over the bottom. Out-pluming dense water and phytoplankton entrained therein eventually sink down and are then re-entrained in the main current as indicated in Fig. 2. However, the extension of plumes still remains unclear. High SE values of $\sigma$-t means along plumes of dense water in the upper 100 to $150 \mathrm{~m}$ of the water column extending laterally for up to $700 \mathrm{~m}$ (Fig. 7) indicate that these are a transient feature. While the fate of phytoplankton and other suspended organic matter in the twilight zone remains unknown, observations with submersibles show communities of benthic filter feeders along the Red Sea continental slope (Fricke \& Hottinger 1983) that may benefit from surface production advected via density flows. Persis- tent north-easterly winds may also cause upwelling off the Arabian coast, bringing viable cells and nutrients back to the surface, thus providing the inoculum for the buoyancy-driven flow of phytoplankton-rich surface water to the coast. Proof of this hypothesised circulation cell cross-linking the pelagic and benthic ecosystems of the Gulf of Aqaba is, however, still lacking.

\section{CONCLUSIONS}

Daily recurring gravity currents are a predominant, yet overlooked, feature driving the cross-shore circulation in the Gulf of Aqaba, a desert-enclosed sea with limited wind-driven and tidal circulation. Our measurements show that gravity currents in the Gulf of Aqaba can travel long distances and may penetrate beyond $300 \mathrm{~m}$ depth. The results presented herein suggest that cooling along the Gulf margins may account for part of the deep mixing in the Gulf of Aqaba, which in exceptional years may exceed $800 \mathrm{~m}$ (Genin et al. 1995). We believe that gravity currents are a widespread phenomenon in the northern Red Sea, where the density stratification is weak and the strong sea surface-air temperature differences result in heavy heat losses in coastal waters. Density currents may play a potentially important, yet unquantified, role in linking the surface and coastal (coral reef) ecosystems with the adjacent ocean by translocation of phytoplankton and other suspended matter to foodimpoverished deeper layers of the twilight zone. This mechanism may be particularly important in the light of the extremely small size of the phytoplankton ( $>95 \%$ of biomass), consisting mostly of cells $<5 \mu \mathrm{m}$ (Lindell \& Post 1998, Yahel et al. 1998). Benthic suspension feeder communities of the twilight zone (Fricke \& Knauer 1986, Fricke et al. 1987) may profit from or even depend on this source of food. A return loop of nutrient-enriched phytoplankton to the surface due to Ekman upwelling may close the trophic cycle between the pelagic, shallow and deep benthic ecosystems.

Acknowledgements. We are most thankful to the following institutions and people for their contributions to this work: the German Ministry for Education and Research (Red Sea Program [RSP] grant: 03F0245A/9), the German Academic Exchange Service as well as Angelika Steffen for various support and funding, the Marine Science Station (MSS), Max Planck Institute for Marine Microbiology, Center for Tropical Marine Ecology and the associated ISATEC-Program for coordination and logistics; R. Manasrah and K. Al-Sokhni for discussion and planning of the field work; Y. Ahmed, R. Al-Khonja, M. Al-Omoor, C. McInerney, N. Odat and A. Niemann for data collection; M. Birkicht for assistance in data processing; G. Krause for discussions and advice; the people of Jordan for their hospitality. 


\section{LITERATURE CITED}

Assaf G, Kessler J (1976) Climate and energy exchange in Gulf of Aqaba (Eilat). Monthly Weather Review 104: 381-385

Badran MI (2001) Dissolved oxygen, chlorophyll a and nutrient seasonal cycles in waters of the Gulf of Aqaba, Red Sea. Aquat Ecosyst Health Manag 4(2001):139-150

Berman T, Paldor N, Brenner S (2000) Simulation of winddriven circulation in the Gulf of Elat (Aqaba). J Mar Sys 26:349-365

Delesalle B, Buscail R, Carbonne J, Courp T, Dufour V, Heussner S, Monaco A, Scrimm M (1998) Direct measurements of carbon and carbonate export from a coral reef ecosystem (Moorea Island, French Polynesia). Coral Reefs 17: 121-132

Didden N, Maxworthy T (1982) The viscous spreading of plane and axisymmetric gravity currents. J Fluid Mech 121:27-42

Fricke HW, Hottinger L (1983) Coral bioherms below the euphotic zone in the Red Sea. Mar Ecol Prog Ser 11: 113-117

Fricke HW, Knauer B (1986) Diversity and spatial pattern of coral communities in the Red Sea upper twilight zone. Oecologia 71:29-37

Fricke HW, Vareschi E, Schlichter D (1987) Photoecology of the coral Leptoseris fragilis in the Red Sea twilight zone (an experimental study by submersible). Oecologia 73: 371-381

Genin A, Paldor N (1998) Changes in the circulation and current spectrum near the tip of the narrow, seasonally mixed, Gulf of Elat. Isr J Earth Sci 47:87-92

Genin A, Lazar B, Brenner S (1995) Vertical mixing and coral death in the Red Sea following the eruption of Mount Pinatubo. Nature 377:507-510

Hata H, Suzuki A, Maruyama T, Kurano N, Miyachi S, Ikeda Y, Kayanne H (1998) Carbon flux by suspended and sinking particles around the barrier reef of Palau, western Pacific. Limnol Oceanogr 43:1883-1893

Hempel G, Richter C (2002) Theme section: ecological studies in the Gulf of Aqaba. Results of the Red Sea programme on marine sciences (RSP) and RV 'Meteor', Cruise 44/2. Mar Ecol Prog Ser 239:231-310

Hulings NC (1979) Currents in the Jordan Gulf of Aqaba. Dirasat 6:21-33

Huthance JM (1981) Waves and currents near the continental shelf edge. Prog Oceanogr 10:193-226

Jungclaus JH, Mellor GL (2000) A three-dimensional model study of the Mediterranean outflow. Mar Syst 24:41-66

Klinker J, Reiss Z, Kropach C, Levanon I, Harpaz H, Halics E, Assaf G (1976) Observation on the circulation pattern in the Gulf of Elat (Aqaba). Isr J Earth Sci 25:85-103

Klinker J, Reiss Z, Kropach C, Levanon I, Harpaz H, Shapiro Y (1978) Nutrients and biomass distribution in the Gulf of Aqaba (Elat), Red Sea. Mar Biol 45:53-64

Kneller B, Buckee C (2000) The structure and fluid mechanics of turbidity currents: a review of some recent studies and their geological implications. Sedimentology 47:62-94

Editorial responsibility: Charles Birkeland (Contributing Editor), Honolulu, Hawaii, USA
Leichter JJ, Schellenbarger G, Genovese SJ, Wing SR (1998) Breaking internal waves on a Florida (USA) coral reef: a plankton pump at work? Mar Ecol Prog Ser 166:83-97

Leichter JJ, Stewart HL, Miller SL (2003) Episodic nutrient transport to Florida coral reefs. Limnol Oceanogr 48: $1394-1407$

Levanon-Spanier I, Padan E, Reiss Z (1979) Primary production in a desert-enclosed sea - the Gulf of Elat (Aqaba), Red Sea. Deep-Sea Res 26:673-685

Marcos SA (1970) Physical and chemical oceanography of the Red Sea. Oceanogr Mar Biol Annu Rev 8:73-202

Nadaoka K, Nihei Y, Kumano R, Yokobori T, Omija T, Wakaki K (2001) A field observation on hydrodynamic and thermal environments of a fringing reef at Ishigaki Island under typhoon and normal atmospheric conditions. Coral Reefs 20:387-398

Paldor N, Anati D (1979) Seasonal variations of temperature and salinity in the Gulf of Elat (Aaba), Red Sea. Deep-Sea Res 26:661-672

Pineda J (1994) Internal tidal bores in the nearshore-warmwater fronts, seaward gravity currents and the onshore transport of neustonic larvae. J Mar Res 52:427-458

Pineda J (1999) Circulation and larval distribution in internal tidal bore warm fronts. Limnol Oceanogr 44:1400-1414

Plähn O, Baschek B, Badewien TH, Walter M, Rhein M (2002) Importance of the Gulf of Aqaba for the formation of bottom water in the Red Sea. J Geophys Res DOI: 10.1029/2000JC000342 August 16, 2002

Rasheed M, Badran MI, Richter C, Huettel M (2002) Effect of reef framework and bottom sediment on nutrient enrichment in a coral reef of the Gulf of Aqaba, Red Sea. Mar Ecol Prog Ser 239:277-285

Reiss Z, Hottinger L (1984) The Gulf of Aqaba: ecological micropaleontology. Springer-Verlag, Berlin

Roberts HH, Wilson PA, Lugofernandez A (1992) Biologic and geologic responses to physical processes - examples from modern reef systems of the Caribbean-Atlantic region. Cont Shelf Res 12:809-834

Sturman JJ, Oldham CE, Ivey GN (1999) Steady convective exchange flows down slopes. Aquat Sci 61:260-278

Wilson PA, Roberts HH (1992) Carbonate-periplatform sedimentation by density flows - a mechanism for rapid off-bank and vertical transport of shallow-water fines. Geology 20:713-716

Wilson PA, Roberts HH (1995) Density cascading — off-shelf sediment transport, evidence and implications, Bahama Banks. J Sediment Petrol 65:45-56

Wolanski E, Delesalle B, Gibbs R (1994) Carbonate mud in Mataiva-Atoll, French-Polynesia - suspension and export. Mar Pollut Bull 29:36-41

Wright SW, Jeffrey SW, Mantoura RFC, Llewellyn CA, Bjornland T, Repeta D, Welschmeyer N (1991) Improved HPLC method for the analysis of chlorophylls and carotenoids from marine phytoplankton. Mar Ecol Prog Ser 77: 183-196

Yahel G, Post AF, Fabricius K, Marie D, Vaulot D, Genin A (1998) Phytoplankton distribution and grazing near coral reefs. Limnol Oceanogr 43:551-563

Submitted: February 20, 2002; Accepted: October 27, 2003 Proofs received from author(s): March 3, 2004 